\title{
Dynamic Hip Screw and Proximal Femoral Locking Compression Plate as a Surgical Treatment of Trochanteric Fracture of Femur a Comparative Study
}

\author{
Shashi Kant Suman ${ }^{1}$ Ashok kumar Meena ${ }^{2}$ L.B.Manjhi ${ }^{3}$ \\ Rajendra Institute Of Medical Sciences, Ranchi, Jharkhand, India
}

\begin{abstract}
Trochanteric fracture femur is one of the commonest fracture orthopaedicpractice. Dynamic hip scre $w(D H S)$ is the gold standard procedure for treatment for stable intertrochanteric fractures, however problem a rises with unstable fractures in maintenance of neck shaft angle. Here we arecomparing results oftrochanteric fr actures treated with proximal femoral locking compression plate (PFLCP) as comparedwith dynamic hip screw (DHS).

Methods: This study was a prospective study. Two groups of trochanteric fractures of 15 patients operated with DHS and 15 with PFLCP were taken. Each patient was followed-up from April 2014 to April 2015 for minimum of 12 month. Every fracture was classified according to EVAN classification.

Results: Among 15 patient treated with PFLCP, length discrepancy was $0.8 \mathrm{~cm}$ while that for DHS was $1 \mathrm{~cm} . T$ he mean time of unaided walking with PFLCP was 18 weeks while for DHS it was 17 weeks. one case was found with superficial infection in DHS.

Conclusions: Proximal femoral locking plate (PFLCP) is simple, stable for fixation with fewer complications, a nd is an effective method for unstable trochanteric fractures.

Keywords: Trochanteric Fracture, Dynamic Hip Screw(DHS),Proximal Femur Locking Compression Plate(PFLCP)
\end{abstract}

\section{Introduction}

Treatment of trochanteric fracture is a challenge to orthopaedic surgeon. Early restoration of joints moti on with stable fixation of fracture, return to normal physiological function and minimal morbidity is now regard ed as ideal fracture treatment for peritrochantric fracture worldwide.

Trochanteric area includes part of femur from extra capsular neck to a point $5 \mathrm{~cm}$ distal to lesser trochant er. It can be divided into inter or sub trochanteric area. This area bear weight unequally and has different fractur e character.

Trochanteric fracture can be stable or unstable (Evan 1949) depending upon integrity of posteromedial c ortex. Unstable fracture can be converted into stable fracture if medial cortex apposition is obtained after reducti on.

\section{Aims and objective}

To obtain union of fracture in most anatomical and functional position, reduce hospital stay and early mobilisati on.

\section{Objective}

-To compare the result of Dynamic hip screw and proximal femoral locking compression plate as a surgical treat ment of trochanteric fracture of femur

-Assessment of results based on subjective parameters (like pain, ability to squat or cross leg sitting, walking), $\mathrm{O}$ bjective parameters (like deformity, range of motion of hip, limb length) and radiological findings and comparis on with previous studies.

\section{Material \& methods}

The material for the present study was obtained from the patients admitted in Department of Orthopaed ics RIMS Ranchi (April 14-April 15) with the diagnosis of subtrochanteric and intertrochanteric fracture femur .Total no. of cases was 30.There were 18 males and 12 females. The average age was 58 years (range 42 to 75 ye ars). 5 patients had polytrauma. The patient s were selected randomly and taken for study. Patients were informe $\mathrm{d}$ about the study in all respects and informed consent was obtained from each patient. Fracture were classified a s stable or unstable (Evan 1949) depending upon integrity of posteromedial cortex.

Out of 30 cases 15 were treated by DHS \& 15 were treated by proximal femoral locking compression plate (PFL $\mathrm{CP})$. 


\section{Observation}

Table 1 (Side of limb involved):

\begin{tabular}{|l|l|l|}
\hline Side of limb & DHS(No. of patient) & PFLCP(No. of patient) \\
\hline Right & 6 & 8 \\
\hline Left & 9 & 7 \\
\hline Total & 15 & 15 \\
\hline
\end{tabular}

Table 2 (Range of movement at knee at the end of $24^{\text {th }}$ week):

\begin{tabular}{|l|l|l|}
\hline R.O.M & DHS & PFLCP \\
\hline$<90$ & 0 & 0 \\
\hline$<110$ & 0 & 0 \\
\hline$<130$ & 3 & 4 \\
\hline Full rom & 12 & 11 \\
\hline
\end{tabular}

Table 3 (Range of movement at hip at the end of $24^{\text {th }}$ week):

\begin{tabular}{|l|l|l|}
\hline R.O.M & DHS & PFLCP \\
\hline$<90$ & 0 & 0 \\
\hline$<110$ & 1 & 1 \\
\hline$<130$ & 1 & 4 \\
\hline Full rom & 13 & 10 \\
\hline
\end{tabular}

Table 4 (Radiological union):

\begin{tabular}{|l|l|l|l|l|l|l|l|l|}
\hline Amount of callus & \multicolumn{2}{|l|}{ D.H.S } & \multicolumn{2}{|l|}{ P.F.L.C.P } \\
\cline { 2 - 10 } & $6^{\text {th }} \mathrm{wk}$ & $12^{\text {th }} \mathrm{wk}$ & $18^{\text {th }} \mathrm{wk}$ & $\begin{array}{l}24^{\text {th }} \mathrm{w} \\
\mathrm{k}\end{array}$ & $6^{\text {th }} \mathrm{wk}$ & $12^{\text {th }} \mathrm{wk}$ & $\begin{array}{l}18^{\text {th }} \\
\mathrm{wk}\end{array}$ & $24^{\text {th }} \mathrm{wk}$ \\
\hline visible callus & 1 & & & & 1 & & & \\
\hline $\begin{array}{l}\text { Little amount of call } \\
\text { us }\end{array}$ & 9 & 1 & & & 8 & 2 & & \\
\hline $\begin{array}{l}\text { Fair amount of callu } \\
\text { s }\end{array}$ & 5 & 10 & 1 & & 6 & 9 & 2 & \\
\hline $\begin{array}{l}\text { Good amount of call } \\
\text { us }\end{array}$ & 4 & 14 & 15 & & 4 & 13 & 15 \\
\hline
\end{tabular}

Table 5 (Complication):

\begin{tabular}{|l|l|l|}
\hline Complication & DHS & PFLCP \\
\hline Superficial infection & 1 & 0 \\
\hline Shortening & 3 & 1 \\
\hline Coxa vara & 3 & 1 \\
\hline
\end{tabular}

\section{Discussion}

In patient with trochanteric fracture union is not a problem if left untreated it generally unite because th is area is of cancellous bone. If treated conservatively coxa vara and shortening develops, thus since last 3-4 dec ades treatment has changed significantly from conservative to operative side. A large no. of fixation implants ha $\mathrm{s}$ been devised and discarded. Differences still exist regarding the type of implant to be used. Treatment still dep ends upon type of fracture and condition of patients.

The present study tries to compare the treatment outcomes of trochanteric fractures internally fixed wit $\mathrm{h}$ dynamic hip screw plate and proximal femoral locking compression plate. In this study, mean age of the patie nts was 58 years. This is comparable with the studies done by Luo et al, Wang et al and Zhu et al, whom noted $t$ he mean age of patients greater than 60 years of age in their studies.In our series, start knee mobilization within 3 days post operatively. Average stay in hospital, it was 13 days in both LCP group and DHS group.Patients who stay more than 15 days in hospital were because of some uneventful complication,

like infection. In our series, union was observed in 14 cases of PFLCP and 15 cases of DHS. Average ti me of union was 18 weeks (12-24 weeks) in PFLCP group and 17 weeks (10-24 weeks) in DHS group. In DHS group 3 patients had limb shortening with themean of $1 \mathrm{~cm}$, while inPFLCP group, only 1 patients had limb shor tening with mean of only $0.8 \mathrm{~cm}$ This may be due to the fact that in PFLCP there was very little collapse at the

fracture site postoperatively. In case of PFLCP with shortening, we found that the fracture was fixed wi th some varus angulation preoperatively. While with DHS we found successive increase in varus angulation wit $\mathrm{h}$ each follow up. This may show the sliding nature of the lag screw of the DHS, which lead to compression at th e fracture site and gradualshortening of limb. PFLCP provides stable anatomical fixation of more comminuted fr acture without shortening of abductor moment arm or changing proximal femoral anatomy. This is comparable $\mathrm{t}$ o other studies like Luo et al, Wang et al and Zhu et al which support PFLCP as good implant for unstable intert rochanteric fracture.In DHS group one patient had superficial infection which was managed by antibiotic covera ge and dressing. Although LCP is a good implant for unstable intertrochanteric fracture but cost of PFLCP is hig $\mathrm{h}$ as compared to the DHS. So, DHS is an economical implant. Fluoroscopic exposure with the PFLCP is quite $\mathrm{h}$ 
igh as compared to DHS, because insertion of three neckscrew required fluoroscopic guidance. So, DHS is still gold standard for stable type of intertrochanteric fracturefemur.

\section{DHS or PFLCP:}

The sliding hip screw with plate remained the gold standard for fixation of trochanteric fracture for yea rs.DHS is still the implant of choice in stable type of fracture In the more comminuted fracture and osteoporotic bone PFLCP has DISTINCT ADVANTAGES over DHS and should be preferred implant for fixation. There is need of anatomical reduction is mandatory since there is no sliding with this implant, any gap at fracture site aft er fixation always lead to non-union.

In conclusion both the implants are here to stay; it is the fracture geometry \& bone quality which will $\mathrm{i}$ nfluence the choice of fixation. The quality of the reduction \& proper positioning of the implant are the keys to a chieving the best postoperative outcome.

\section{References}

[1]. DeLee JC, Clanton TO, Rockwood CA Jr. Closed treatment of Subtrochanteric fracture of the femur in a modifiedcastbrace. J Bone Joint SurgAmer 1981; 63: 773-9.

[2]. Robinson CM, Court-Brown CM, McQueen MM, Christie J. Hip fractures in adults younger than 50 years of age. Epidemiology and results.ClinOrthopRelat Res 1995; 312: 238-46.

[3]. Kim WY, Han CH, Park Ji, Kim JY. Failure of intertrochantric fracture fixation with dynamic hip screw in relation to preoperative fracture stability and osteoporosis. In Ortho.2001;25:360-2.

[4]. Fogagnolo F, KfuriJr M, Paccola C. Intramedullary fi xation of pertrochanteric hip fractures with the short AO-ASIF proximal femoral nail. Arch Orthop Trauma Surg 2004; 124: 31 .

[5]. Robinson CM, Houshian S, Khan LAK. Trochanteric-entry long cephalomedullary nailing of subtrochanteric fractures caused by low-energy trauma.J Bone Joint SurgAmer 2005; 87: 2217-26.

[6]. Pajarinen J, Lindahl J, Michelsson O et al. Pertrochanteric femoral fractures treated with a dynamic hip screw or a proximal femoral nail. A randomised study comparing post-operative rehabilitation.J Bone Joint Surg Brit 2005; 87: 76-81.

[7]. Ekström W, Karlsson-Thur C, Larsson S, Ragnarsson B, Alberts KA. Functional outcome in treatment of unstable trochanteric and subtrochanteric fractures with the proximal femoral nail and the Medoff sliding plate. J Orthop Trauma 2007; 21: 18-25.

[8]. Campbell WC, Canale ST, Beaty JH. Campbells operative orthopaedics. 11th edition.Philldelphia, PA: Mosby Elsevier; 2008

[9]. Oh CW, Kim JJ, Byun YS et al. Minimally invasive plate osteosynthesis of subtrochanteric femur fractures with a locking plate: a prospective series of 20 fractures. Arch Orthop Trauma Surg 2009; 129: 1659-65.

[10]. Saarenpaa I, Heikkinen T, Ristiniemi J. Functional comparison of the dynamic hip screw and the gamma locking nail in trochanteric hip fractures: a matchedpair study of 268 patients. Int'l Orthop 2009; 33: 255-60.

[11]. Wieser K, Babst R. Fixation failure of the LCP proximal femoral plate 4.515.0 in patient with missing posteromedial support in unstable pre-, inter-, and subtrochanteric fractures of the proximal femur. Arch Orthp Trauma surg. 2010;130:1281-7

[12]. Parker, MJ, Handoll HH. Gamma and other cephalocondylic intramedullary nails versus extramedullary implants for extracapsular hip fractures in adults. Cochrane Database Syst Rev. 2010 Sep 8;(9):

[13]. ZhaGc Chen ZL, Qi XB, Sun JY. Treatment of pertrochanteric fractures with a proximal femur locking compression plate. Surgery. 2011;42(11):1294-9.

[14]. Zhu QL, Yan MH, Zhao LL, Xu B, Rong LJ, Luo JM. Analysis of treatment of osteoporotic intertrochantric fracture of femur with the locking compression plate (LCP).ZhongguoGu Shang. 2011;24(5):378-81

[15]. Wang Y, Yang YY, Yu ZH, Zheng XX. A Comparitive study of intertrochantric fracture with proximal femur locking compress plate in aged. ZhongguoGu Shang. 2011;24(5):370-3.

[16]. Glassner PJ, Tejwani NC.Failure of proximal Femoral Locking Compression Plate; A Case Series.J Orthop Trauma. 2011;25(2):7683. Cite this article as: Meena MK, Joshi V. A comparative study between proximal femur locking

[17]. Meena MK et al. Int J Res Orthop. 2016 Dec;2(4):327-332 International Journal of Research in Orthopaedics | October-December 2016 | Vol 2 | Issue 4 Page 332 